\title{
The Use of Contextual Learning-Based Civic Education Textbook to Increase Student Outcomes in Grade V Elementary School
}

\author{
Aulia Fatwa Fatona ${ }^{1}$, St. Y. Slamet ${ }^{2}$, Winarno ${ }^{3}$ \\ ${ }^{1}$ Master's student of Primary Teacher Education Study Program, Postgraduate Program, Universitas Sebelas Maret, \\ Surakarta, Indonesia \\ ${ }^{2}$ Lecturer of Primary Teacher Education Study Program, Faculty of Teacher Training and Education, Universitas Sebelas \\ Maret Surakarta, Indonesia \\ ${ }^{3}$ Lecturer of Civic Education Study Program, Faculty of Teacher Training and Education, Universitas Sebelas Maret \\ Surakarta, Indonesia
}

\begin{abstract}
This study aims to determine the effectiveness of the use of contextual learning-based civic education textbook to improve the learning outcomes of grade $V$ primary school students. This study is a quasi-experiment using pretest-post-test control group design. The subjects were 40 students of grade $V$ primary school consisting of 22 students of experimental class and 18 students of control class. The treatment of experimental class is learning by using the contextual learning-based civic education textbook for 8 meetings. The learning process in the control class is on the same material and time span, but this class is not treated. The technique of collecting the data is using a test. The test instrument consists of 25 multiple choice questions. The result of independent sample t-test showed that the value of $t_{\text {count }}$ is higher than table (5,937>2,024). The results showed that contextual learning-based civic education textbook is effective in improving grade $V$ elementary school students learning outcomes. Improved learning outcomes in the experimental class based on the N-Gain score (0.708) is in high category.
\end{abstract}

Keywords- Civic education, learning outcomes, contextual learning, textbook..

\section{INTRODUCTION}

Pancasila ${ }^{1}$ and Citizenship Education $\left(\mathrm{PPKn}^{2}\right)$ are parts of civic education which are intended for elementary to secondary school students. Civic education itself is an attempt to apply citizenship study. The study of citizenship is the study of the relations among citizens and the relationships between citizens and their country. As a form of discipline, civic education is an education whose main subject is political democracy aimed at students or citizens (Winarno: 2014).

\footnotetext{
${ }^{1}$ Five principles of Indonesia

${ }^{2}$ Pendidikan Pancasila dan Kewarganegaraan
}

Democracy Educati in Civic Education aims to prepare citizens to think critically and act democratically, through the activity of instilling awareness to the young generation, that democracy is a form of community life that guarantees the rights of the people. To achieve these objectives, we need to cultivate the values of Pancasila from an early age through the lessons of PPKn that have existed since elementary school level. PPKn shall be contained in the curriculum of primary, secondary, and higher education which is intended to form learners into human beings who have a sense of nationality and love of the homeland in accordance with Pancasila and the 1945 Constitution (Publisher Team: 2013).

The results of observations which have been conducted indicate that the lessons and assignments methods through the available books lack a positive response from students so that most students are quite in class, looking bored and accept the lessons being taught without really understanding what the teacher actually delivered. The difficulty of students' understanding is that the material in the book is presented in a monotonous, conventional and unfocused way to make it easier for students to understand the existing moral message in the subject matter of PPKn because it only displays material without relating to the real life around the students. The teacher books and student books in the 2013 curriculum are supposed to be provided by the government, but the reality in the field, the distribution is uneven and sometimes there is not enough for students to use in one class. This problem makes the teacher look for other alternatives by buying theme books sold by private publishers. However, the theme book lacks an in-depth discussion of a subject matter, no illustrations or images and no attractive colors which add to the students' boredom. The unavailability of an interesting PPKn textbook that meets these criteria leads to many students do not pass this subject. 
Based on the empirical facts of the results of researches that have been done before, the learning we see now is not in accordance with the mandate of the National education which functions to develop students' ability, shape their characters into civilized and dignified nation, aim for the development of the potential learners to be a human being who believes in and pious to the God Almighty, make students healthy, knowledgeable, capable, creative, independent, become democratic citizens and be responsible throughout the lessons. To make citizens understand and able to exercise their rights and obligations from an early age, students must first understand the material in PPKn lessons and get satisfactory results in the subject. This is due to the lack of innovation in the delivery and provision of learning materials that are able to attract attention and make it easier for students to understand the lesson (Team Publisher: 2013).

Ideally, if students get satisfactory learning outcomes in PPKn learning, then their attitudes will gradually change for the better because they already know clearly the good and the bad (Solihatin: 2014). So it will make it easier to establish citizens who understand and able to exercise the rights and obligations to become Indonesian citizens who are smart, skilled, and well-characterized.

If the failed students in this PPKn subject are not immediately helped, it will be a protracted problem and will result in social life. Because in the elementary level and in the lessons of PPKn, students learn about the basics of rights and obligations in the social environment (Team Publisher: 2013). So it is very important that the groundbreaking PPKn textbooks be innovative, interesting and able to facilitate students to understand the materials contained in it.

Contextual learning system aims to help students see meanings in the learning material by connecting it with the events of everyday life whether in personal, social, and cultural life. Contextual learning also provides facilities for students learning activities to seek, process, and discover concrete learning experiences through the involvement of students who have tried, done, and experienced themselves (Rusman: 2014). The existence of such learning is seen not only from the side of the results, but most importantly is the process. This contextual learning can make students understand the real concept, think deeper because they are trained to think according to problems and existing data to solve the problems, have a more meaningful learning, increase motivation to learn and solve problems, become independent and ultimately passing the test is expected to be achieved (Budiyanto: 2016).

Based on the development research conducted by previous researchers, there were differences of conventional class post-test and experimental class on the syntactic ability of Indonesian language using contextual learning. From the calculation, the average score for the post-test in the conventional class is 70.45 , while the average score for post-test is 79.24. This shows that the average post-test score is greater than the average pretest score. Thus, the effectiveness of the test results with textbooks of contextual syntactic approaches is well classified (Wahyuni: 2015).

Based on the above background description, the use of contextual learning-based civic education textbook is expected to improve the learning outcomes in PPKn subject. The problem formulation of this research is how the effectiveness of contextual learning-based civic education textbook improve the learning outcomes of the fifth grade elementary school students? The objective of this research is to determine the effectiveness of contextual learning-based civic education textbook to increase learning outcomes in the subject of PPKn for the fifth grade students of elementary school.

\section{METHOD}

This research is an experimental quasi research using pretest - post-test control group research design (Cresswell: 2008). The design of this study is to compare between the experimental group which was given the treatment using contextual learning-based civic education textbook and control group using the textbook commonly used today. Prior to the treatment, all subjects were given a pretest, then after the treatment they were given a posttest. The treatment was done by implementing the contextual learning-based civic education textbook on fifth grade elementary school students. The research design can be observed in Table 1 .

Table. 1: Research Design

\begin{tabular}{cccc}
\hline \multicolumn{1}{c}{ Group } & \multicolumn{3}{c}{ Research Activities } \\
Experimental Group (N=22) & $\mathrm{O}_{1}$ & $\mathrm{X}_{1}$ & $\mathrm{O}_{2}$ \\
Control Group (N=18) & $\mathrm{O}_{1}$ & $\mathrm{X}_{2}$ & $\mathrm{O}_{2}$ \\
\hline $\mathrm{O} 1 \quad$ : Pretest \\
$\mathrm{O} 2$ & : Post-test \\
$\mathrm{X} 1$ & : Treatment using contextual learning-based civic education textbook \\
$\mathrm{X} 2$ & : Using current textbook
\end{tabular}


Based on Table 1, the study subjects consisted of 18 control group students and 22 students of the experimental group. Both groups came from two elementary schools in Sragen regency. The first step is to provide the pretest questions of the control group and the experimental group. The pretest consists of 25 multiple choice questions done in 40 minutes. After being given a pretest, the next step is to provide a treatment using a contextual learning-based civic education textbook in the experimental group. No treatment is given to the control group learning activities which used the current textbook.
The materials taught in both groups were the same which were "The Application of Pancasila Values in Everyday Life and the Rights, Obligations and Responsibilities of Citizens". The learning process in both groups is done three times in one week and 70 minutes per meeting. The total implementation of learning process is 8 meetings. The next step is to provide post-test questions on the experimental group and the control group. The post-test consists of 25 multiple choice questions done in 40 minutes. The whole series of research activities was conducted in 3 weeks with a summary of research activities shown in Table 2.

Table. 2: Summary of Research Activities

\begin{tabular}{cl}
\hline Meeting & \multicolumn{1}{c}{ Research Activities } \\
\hline 1 & Pretest \\
$2-5$ & Learning the Application of Pancasila Values \\
$6-9$ & Learning the Rights, Obligations and Responsibility of Citizens \\
10 & Posttest
\end{tabular}

Based on Table 2, the research activities at the first meeting is to provide pretest questions on the experimental group and the control group. The second meeting provides treatment by implementing contextual learning-based civic education textbook for 8 meetings to the experimental group. The control group uses the current textbook. The learning process of the second to fifth meeting is on the material "Application of Pancasila Values in Everyday Life". At the sixth to ninth meetings, the classes talked about "Rights, Obligations, and Responsibilities of Citizens". At the tenth meeting, the experimental group and the control group were given the post-test questions.

The instruments of the pretest and post-test questions in this study are mostly the problems related to and exist around the students. The development of the dilemma instrument was adapted from the material and the competence of grade V PPKn. To determine the effectiveness of contextual learning-based civic education textbook against PPKn learning outcome, there is a twostep analysis used in this study. The first step is to calculate the significance of the mean difference of the post-test from the experimental group and the control group. This test is done by using independent sample ttest. The purpose of this test is to know the difference of the groups' average which was given treatment and not given treatment. The process of calculating independent sample t-test is done by using SPSS (Statistical Product and Service Solutions) software. The treatment is effective if the value of $t_{\text {count }}$ is greater than $t_{\text {table }}$.
Once it is known that the treatment provided is significantly effective towards the improvement of the learning outcomes of PPKn, then the next step is to measure how much increase occurs between before and after the treatment. The increase result is calculated using the Normalized Gain (N-Gain) formula as follows (Meltzer: 2002).

$$
g=\frac{\text { posttest score }- \text { pretest score }}{\text { max score }- \text { pretest score }}
$$

The criteria used in the N-Gain count results are based on the assessment standard described in Table 3 (Hake: 1998) .

\begin{tabular}{cc} 
Table. 3: $N$-Gain & Score Criteria \\
\hline N-Gain & Category \\
\hline $\mathrm{g}<0.3$ & Low \\
$0.7>\mathrm{g} \geq 0.3$ & Medium \\
$\mathrm{g} \geq 0.7$ & High \\
\hline
\end{tabular}

Contextual learning-based civic education textbook can be said to improve learning outcomes of PPKn subject when the score of $\mathrm{N}$-Gain is at least in the medium category.

\section{RESULTS AND DISCUSSION}

The first research activity was conducted by giving pretest to know the initial condition of the students. Prior to use, the pretest and post-test questions have been validated by experts in their field and tested for their 
validity and reliability. All the items used have met the minimum standard of validity test of factorial analysis that is more than 0.3 . The reliability of the questions is 0.85 which means very reliable.

Based on the score of pretest results calculated using SPSS, it is known that the experimental and control groups are derived from normally distributed samples and both have the same or homogeneous variants. The result of normality significance test of control group is 0.658 and the experimental group is 0.321 , so both groups are normally distributed since the result of the count is greater than the alpha value $(>0.05)$. The result of homogeneity test is obtained by a significant level of 0.074 which means that both groups have the same variant because the test result is bigger than alpha (0.05).

After the results of pretest analysis have been claimed as eligible, the treatment began in accordance with the research design. To measure the success of the treatment, the effectiveness test was done using independent sample t-test on post-test result score of experimental group and control group. The effectiveness test results can be observed in Table 4.

Table. 4: Effectiveness Test

\begin{tabular}{ccccccc}
\hline $\begin{array}{c}\text { Control } \\
\text { Group }\end{array}$ & $\begin{array}{c}\text { Experiment } \\
\text { Group }\end{array}$ & $\mathrm{t}_{\text {count }}$ & $\mathrm{t}_{\text {table }}$ & Significance & Reception & Conclusion \\
\hline 58889 & 80909 & 5.937 & 2,024 & 0.05 & $\mathrm{H}_{\mathrm{a}}$ accepted & $\begin{array}{c}\text { Effective contextual } \\
\text { learning based textbooks }\end{array}$ \\
\hline
\end{tabular}

Based on Table 4, the average post-test value of the control group is 58,889 whereas the experimental group is 80,909 . The mean score of the experimental group is higher than the control group. Based on the calculation of t-test which used independent sample t-test obtained $t_{\text {count }}$ 5,987 whose value is greater than $t_{\text {table }}$ which is 2,024 $(5,987>2,024)$. When viewed from the significance of the t-test results, the significance value is lower than the alpha value $(0.000<0.05)$. The t-test results indicate that there is a significant difference of increase between the experimental group and the control group. To find out how big the difference of improvement in both groups, $\mathrm{N}$ Gain test was done. The result of N-Gain test in both groups can be observed in Table 5.

Table. 5: N-Gain Average Improvement Analysis

\begin{tabular}{ccc}
\hline Average & Control Group & Experimental Group \\
\hline Pretest & 56889 & 54 \\
Post-test & 58998 & 80909 \\
N-Gain Score & 0.105 & 0.708 \\
N-Gain Criteria & Low & High \\
\hline
\end{tabular}

Table 5 shows that $\mathrm{N}$-Gain score of the experimental group which was given instructional treatment using the contextual learning-based civic education textbook is higher than the N-Gain score of the control group which was not treated $(0.708>0.105)$. Based on the N-Gain score criteria, the improvement of learning outcomes of PPKn in the experimental class is in high category. In the control group, the increase that occurred is in low category. The result of $\mathrm{N}$-Gain score has answered the question of problem formulation about the effectiveness of the contextual learning-based civic education textbook in improving learning outcomes of grade $\mathrm{V}$ students of elementary school.

Contextual learning is a concept that helps teachers link the content to be studied by real-world situations and encourage students to make connections between the knowledge possessed by the application in their lives as members of the family and society. In the learning process, the teacher relates between the material he teaches with real life situations and encourages students to make the relationship between their knowledge and application in daily life so that learning is more meaningful (Suprijono: 2009). In addition, the process of the active involvement of students in solving and having higher thinking skills is due to the problems solving skills by using existing data to find results which is a stimulus to students to be able to be immersed in the problems and make them more independent (Budiyanto: 2016). The various positive impacts resulted in the use of contextual learning components in the learning activities show the advantages of contextual learning as a means of learning in schools.

Contextual learning stages start from invitation, exploration, explanation and solution, and eventually the action making so that students can make decisions using their knowledge and skills. Various information and ideas have encouraged students to ask follow-up questions and suggest both as an individual or as a part of a group related to problem-solving so that what is learned can be understood better (Sa'ud: 2009). Contextual learning 
encourages students to apply in real life what they have learned in class. Contextual learning not only expects students to understand the material learned, but how the subject matter can color the behavior in everyday life. Lesson material in contextual learning is not to be stacked in the brain and then be forgotten, but as a provision for the students to face reality (Al-Tabany: 2015).

Using contextual learning in the classroom does not involve new tools, it only involves teaching styles and strategies. Teachers can maximize the outcomes of this lesson by applying contextual learning strategies that are taught by connecting what is taught into real-world contexts, experiencing new knowledge, applying new concepts to real-world situations, solving problems by communicating with each other, and transferring that knowledge to the experience they will get in the future (Davtyan: 2014).

Textbook is a teaching material in the form of print/written media in which summarized the learning materials. A good textbook not only contains the correct scientific concepts and interesting contents, but most importantly it should be able to make students learn. With reference to contextual approacch, in developing textbooks, one must assume the objectives of the subject which contains general principles of textbook writing, the integration of contextual learning components with the components of learning strategies and learning message design principles (Komalasari: 2017).

Improving learning outcomes of PPKn as a result of the use of textbooks based on contextual learning is expected to have implications on the character and personality of students. In addition, to impact on the formation of character and personality, the development of students' skills on the cognitive aspect is one of the efforts to improve the sense of nationality and love of the homeland in accordance with Pancasila and the 1945 Constitution. The ability to think critically is one of the goals of learning PPKn. The purpose of PPKn is not only to build good citizens, but smart citizens in facing the environment of their lives (Wahab: 2011). Therefore, the development of textbooks using contextual learning that accommodate various problems in the community is expected to prepare students to become one of the members of the community who are ready and able to solve various problems that exist to achieve civil society (Erwin: 2013).

\section{CONCLUSION}

The use of textbooks based on contextual learning is effective towards improving learning outcomes of grade $\mathrm{V}$ primary school students. The statement is supported by the indenpendent sample $t$-test obtained, $t_{\text {count }} 5,937$ whose value is greater than $t_{\text {table }} 2.024$ (5.937> 2.024).
When viewed from the significance of t-test results, the significance value is lower than the alpha value $(0.000$ <0.05). Furthermore, the $\mathrm{N}$-Gain score of the experimental class which was given instructional treatment using contextual learning based civic education textbook is higher than N-Gain score of control group that was not given treatment $(0.708>0.105)$.

This research is limited to the lessons of PPKn in primary school, further research is expected to develop textbooks on other subjects or even in integrative thematic learning in primary schools. At the school level above, contextual learning can also be tested to develop textbooks and learning media on all subjects and lines of education.

\section{ACKNOWLEDGEMENTS}

Thanks to all the students and teachers of primary schools in Sragen who have supported this research so it could go smoothly. The autors are also grateful to the experts who have validated the products and instruments of this research.

\section{REFERENCES}

[1] Al-Tabany, T. I. B. (2015). Mendesain Model Pembelajaran Inovatif, Progresif, dan Kontekstual. Jakarta: Prenadamedia Group.

[2] Budiyanto, A. K. (2016). Sintaks 45 Model pembelajaran dalam Student Centered Learning (SCL). Malang: UMM Press.

[3] Cresswell, J. W. (2008). Planning, Conducting, and Evaluating Quantitative and qualitative research Fourth ed. Boston: Pearson Education.

[4] Davtyan, R. (2014). Contextual Learning. ASEE 2014 Zone I Conference, April 3-5, 2014, University of Bridgeport, Bridgpeort, CT, USA.

[5] Erwin, M. (2013). Pendidikan Kewarganegaraan Republik Indonesia (Edisi Revisi). Bandung: PT Refika Aditama.

[6] Hake, R. R. (1998). Interactive-Engagement vs Traditional Methods: A Six-Thousand-student Survey of Mechanics Test Data for Introductory Physics Courses. American Journal on Physics, vol. 66, pp. 64-74.

[7] Komalasari, K. (2017). Pembelajaran Kontekstual: Konsep dan Aplikasi. Bandung: Refika Aditama.

[8] Meltzer, D. E. (2002). The Relationship between Mathematics Preparation and Conceptual Learning Gains in Physics: a Possible Hidden Variable in Diagnostic Pretest Scores, American Journal on Physics, vol. 70, pp. 1259-1268.

[9] Rusman. (2014). Model-model pembelajaran: Mengembangkan Profesioalisme Guru. Jakarta: Rajawali Press. 
[10] Sa’ud, U. S. (2009). Pengembangan Profesi Guru. Bandung: Alfabeta.

[11] Solihatin, E. (2014). Strategi Pembelajaran PPKn. Jakarta: Bumi Aksara.

[12] Suprijono, A. (2009). Cooperative Learning: Teori dan Aplikasi Paikem. Yogyakarta: Pustakan Pelajar.

[13] Tim Penerbit. (2013). Himpunan Peraturan Perundang-Undangan: Undang-Undang Sisdiknas (Sistem Pendidikan Nasional). Bandung: Fokus Media.

[14] Wahab, A. A., \& Sapriya. (2011). Teori dan Landasan Pendidikan Kewarganegaraan. Bandung: Alfabeta.

[15] Wahyuni, T., Suwandi, S., Slamet, St. Y., \& Andayani. (2015). The Implementation of Contextual Approach in Solving Problems Understanding Syntax : Sentence Indonesian at universities in Surakarta, Indonesia. Journal of Education and Practice, vol. 6(30), pp. 188-201.

[16] Winarno. (2014). Pembelajaran Pendidikan Kewarganegaraan: Isi, Strategi dan Penilaian. Jakarta: Bumi Aksara. 